STUDIA Z PRAWA WYZNANIOWEGO

Tom $21-2018$

DOI: https://doi.org/10.31743/spw.200

KONRAD DYDA*

\title{
PRAWO I OBOWIĄZEK PRZETWARZANIA DANYCH OSOBOWYCH BYŁYCH WYZNAWCÓW PRZEZ KOŚCIOŁY I INNE ZWIĄZKI WYZNANIOWE
}

\section{Streszczenie}

Konstytucja RP poręcza kościołom i innym związkom wyznaniowym autonomię i niezależność - zasada ta ma na celu zagwarantowanie swobodnej realizacji prawa do wolności religijnej jednostki. Aby móc w pełni urzeczywistniać swoje cele związek wyznaniowy musi m.in. przetwarzać dane osobowe swoich członków. Jednak w praktyce powstaje problem, czy wraz z formalnym wystąpieniem z kościoła należy zaprzestać przetwarzania danych osobowych byłego wyznawcy. Jak dotąd w doktrynie i orzecznictwie ukształtowano różnorodne rozwiązania tej kwestii. W artykule podjęto próbę znalezienia odpowiedzi na pytanie, czy konstytucyjna pozycja związków wyznaniowych uprawnia do przetwarzania danych osobowych byłych wyznawców. Kanwą dla przeprowadzonych analiz stało się postanowienie Naczelnego Sądu Administracyjnego z dnia 21 maja 2018 roku. Autor pozytywnie odpowiadając na tak postawione pytanie wskazał, że jest to niezbędne zarówno dla realizacji wolności religijnej innych wyznawców danej wspólnoty wyznaniowej, jak i konieczne ze względu na przepisy prawa powszechnie obowiązującego. Zgodnie bowiem z ustawą o narodowym zasobie archiwalnym i archiwach dane byłych członków związku wyznaniowego stanowią Narodowy Zasób Archiwalny, stąd każdy kościół jest zobowiązany je chronić i nie ma prawa dokonywać jakichkolwiek zmian w ich treści. Dlatego apostata nie ma prawa do skutecznego żądania wykreślenia jego danych ze zbiorów prowadzonych przez kościoły i inne związki wyznaniowe. Dokonanie takiej czynności przez administratora danych mogłoby narazić go na odpowiedzialność prawną.

* Mgr lic., doktorant w Katedrze Prawa Wyznaniowego, Wydział Prawa, Prawa Kanonicznego i Administracji, Katolicki Uniwersytet Lubelski Jana Pawła II, Al. Racławickie 14, 20-950 Lublin, e-mail: konrad.dyda@gmail.com. ORCID 0000-0002-2061-7839. 
Słowa kluczowe: przetwarzanie danych osobowych; autonomia i niezależność; związek wyznaniowy; apostazja

$* * * * *$

W związku z rozpoczęciem stosowania z dniem 25 maja 2018 roku Rozporządzenia Parlamentu Europejskiego i Rady (UE) 2016/679¹ - kwestia ochrony danych osobowych stała się przedmiotem szerokiego zainteresowania opinii publicznej. Wiele wprowadzonych przez prawodawcę unijnego rozwiązań ma charakter iście rewolucyjny. Do tej grupy - w perspektywie rozbieżności w orzecznictwie sądowoadministracyjnym i działalności Generalnego Inspektora Ochrony Danych Osobowych (GIODO) - można zaliczyć dopuszczenie przetwarzania przez związki wyznaniowe danych osobowych byłych wyznawców (art. 9 ust. 2 pkt d RODO), przy jednoczesnym nałożeniu na kościoły szeregu obowiązków związanych z zapewnieniem prawidłowej ochrony danych osobowych swoich członków ${ }^{2}$. Co prawda nowe rozwiązania prawne nie znajdą zastosowania do aktów wystąpienia ze związku wyznaniowego dokonanych przed 25 maja br., jednak w świetle postanowienia składu siedmiu sędziów Naczelnego Sądu Administracyjnego z dnia 21 maja 2018 roku $^{3}$ ciągle otwartym pozostaje czy dokonanie apostazji przez wyznawcę uprawnia go do żądania wykreślenia wszelkich informacji o sobie ze zbiorów danych prowadzonych przez kościoły. Z pewnością jest to jeden z głównych problemów pojawiających się w dotychczasowym orzecznictwie sądowoadministracyjnym dotyczącym przetwarzania danych osobowych przez związki wyznaniowe i ustalenia uprawnień kontrolnych GIODO w tym zakresie ${ }^{4}$.

Celem niniejszego artykułu jest odpowiedź na powyższą wątpliwość przede wszystkim w perspektywie powołanego judykatu NSA oraz zasady

1 Rozporządzenie Parlamentu Europejskiego i Rady (UE) 2016/679 z dnia 27 kwietnia 2016 r. w sprawie ochrony osób fizycznych w związku z przetwarzaniem danych osobowych i w sprawie swobodnego przepływu takich danych oraz uchylenia dyrektywy 95/46/ WE (ogólne rozporządzenie o ochronie danych), Dziennik Urzędowy Unii Europejskiej z 2016 r., L 119/1; dalej: RODO.

2 Zob. Hucał 2017, 185-222.

3 Sygn. akt I OPS 6/17, Centralna Baza Orzeczeń Sądów Administracyjnych.

4 Zob. Hucał 2018, 5-23. 
autonomii i niezależności kościołów i innych związków wyznaniowych. Jak już wspomniano, ciągle - pomimo zmiany regulacji prawnych - nie jest to spór jedynie teoretyczny.

1. ZAKRES WNIOSKU RZECZNIKA PRAW OBYWATELSKICH I ORZECZENIE NACZELNEGO SĄDU ADMINISTRACYJNEGO

Pismem z dnia 19 października 2017 roku Rzecznik Praw Obywatelskich (RPO) ${ }^{5}$ zwrócił się do Naczelnego Sądu Administracyjnego o rozstrzygnięcie dwóch zagadnień prawnych, co do których zauważył rozbieżności w orzecznictwie sądów administracyjnych. Pierwsze dotyczyło odpowiedzi na pytanie: czy ustalając przynależność osoby do Kościoła Katolickiego dla potrzeb zastosowania przepisów ustawy z dnia 29 sierpnia 1997 r. o ochronie danych osobowych ${ }^{6}$, Generalny Inspektor Ochrony Danych Osobowych musi opierać się wyłącznie na akcie chrztu z właściwą adnotacją wskazującą na dopełnienie wewnętrznych procedur kościelnych (art. 43 ust. $2 \mathrm{w}$ zw. z art. 43 ust. 1 pkt 3 i art. 22 UODO w zw. z art. 7, 75 i $77 \S 1$ ustawy z dnia 14 czerwca 1960 r. - Kodeks postępowania administracyjnego ${ }^{7}$ )? Natomiast drugie zagadnienie odnosiło się do analogicznych kwestii w zakresie procedur stosowanych przez niekatolickie związki wyznaniowe i zostało sformułowane w bardziej ogólnym pytaniu: Czy ustalając przynależność osoby do kościoła lub związku wyznaniowego dla potrzeb zastosowania UODO organ powinien oprzeć się wyłącznie na dowodach wynikających z regulacji wewnętrznych danego kościoła lub związku wyznaniowego także wówczas, gdy przedstawienie takiego dowodu z przyczyn niezależnych od strony jest niemożliwe? Zgodnie z deklaracją RPO wniosek ten został złożony na prośbę Generalnego Inspektora Ochrony Danych Osobowych rozpoznającego skargi na proboszczów Kościoła Rzymskokatolickiego, którzy przetwarzają dane osobowe osób, które w sensie kanonicznym skutecznie wystąpiły z tego Kościoła lub też

5 Wniosek Rzecznika Praw Obywatelskich z dnia 10 października 2017 roku, https:// www.rpo.gov.pl/pl/content/wniosek-rpo-do-nsa-w-sprawie-kompetencji-giodo-do-oceny-spraw-apostat \%C3\%B3w [dostęp 6.07.2018].

6 Dz. U. z 2016 r., poz. 922; dalej: UODO.

7 Dz. U. z 2017 r., poz. 1257 z późn. zm. 
złożyły pisemną deklarację o wystąpieniu z niego, jednak nie dopełniły właściwej procedury kanonicznej.

Rzecznik Praw Obywatelskich stanął na stanowisku, że „w świetle dotychczasowego orzecznictwa sądowoadministracyjnego bezspornym pozostaje fakt, że wyłączenie, o którym mowa w art 43 ust. 2 w zw. z art. 43 ust 1 pkt 3 UODO, nie dotyczy osób, które nie są członkami kościoła lub związku wyznaniowego". Natomiast - zdaniem RPO - ,problem sporny w orzecznictwie sądów administracyjnych dotyczy tego, w jaki sposób GIODO ma ustalić, czy dana osoba jest czy też nie jest członkiem danego kościoła lub związku wyznaniowego". Motywując swój wniosek Rzecznik Praw Obywatelskich wskazał na trzy linie orzecznicze, w których sądy administracyjne - w tym Naczelny Sąd Administracyjny - rozstrzygały te kwestie. Według pierwszej z nich ${ }^{8}$ określenie, czy dana osoba skutecznie wystąpiła ze związku wyznaniowego może nastąpić jedynie na podstawie prawa wewnętrznego danego kościoła. Stąd też GIODO powinien ustalić, czy występujący ze wspólnoty wyznaniowej dopełnił wszelkich formalności - określonych przez prawodawstwo konfesyjne - związanych z tego typu aktem. Do drugiej grupy orzeczeń RPO zakwalifikował judykaty zakładające dokładnie odwrotny sposób rozstrzygania kwestii wystąpienia ze wspólnoty wyznaniowej ${ }^{9}$. Zgodnie z nimi skuteczność tego aktu może zostać oceniona jedynie na podstawie przepisów powszechnie obowiązującego prawa (państwowego). W tym stanowisku za podstawowy argument podaje się założenie, że takie kwestie jak wstąpienie, czy wystąpienie ze związku wyznaniowego są ich sprawą wewnętrzną, o ile nie dotykają uprawnień lub obowiązków wyznawcy gwarantowanych przepisami powszechnie obowiązującego prawa. Do tych ostatnich sądy zaliczyły ochronę danych osobowych. W trzeciej grupie orzeczeń ${ }^{10}$

8 Do pierwszej grupy RPO zaliczył następujące orzeczenia: wyrok NSA z dnia 24 października 2013 roku, sygn. akt I OSK 1520/13; wyrok NSA z dnia 27 marca 2013 roku, sygn. akt I OSK 932/12; wyrok NSA z dnia 4 kwietnia 2013 roku, sygn. akt I OSK 897/12.

9 Do drugiej grupy RPO zaliczył następujące orzeczenia: wyrok NSA z dnia 18 października 2013 roku, sygn. akt I OSK 1487/12; wyrok NSA z dnia 18 października 2013 roku, sygn. akt I OSK 1339/13; wyrok NSA z dnia 18 października 2013 roku, sygn. akt I OSK 2541/12; wyrok NSA z dnia 18 października 2013 roku, sygn. akt I OSK 129/13 wyrok NSA z dnia 24 października 2013 roku, sygn. akt I OSK 1828/12.

10 Do trzeciej grupy RPO zaliczył następujące orzeczenia: wyrok NSA z dnia 9 lutego 2016 roku, sygn. akt I OSK 1509/15; wyrok NSA z dnia 9 lutego 2016 roku, sygn. akt I OSK 
sądy administracyjne stanęły na stanowisku, że GIODO w ogóle nie jest organem kompetentnym do dokonywania oceny skuteczności wystąpienia z kościoła. Dlatego Generalny Inspektor Ochrony Danych Osobowych może skorzystać ze swoich uprawnień jedynie w sytuacji, gdy występujący z Kościoła przedłoży mu akt chrztu ze stosowną adnotacją. W braku takiego dokumentu GIODO musi umorzyć postępowanie w sprawie o nakazanie przywrócenia stanu zgodnego z prawem przez uaktualnienie danych osobowych.

Ponadto Rzecznik Praw Obywatelskich zauważył, że argumentacja przedstawiona w tej trzeciej linii orzeczniczej w żaden sposób nie ustosunkowuje się do problemu, jakie dowody mają przedstawić osoby, które są członkami związków wyznaniowych nie przewidujących w swojej doktrynie obrzędów chrztu. Jednocześnie RPO stanął na stanowisku, że w przypadku danych osobowych osób, które nie należą do Kościoła Katolickiego GIODO zachowuje pełnię swoich uprawnień - a więc w momencie wystąpienia formalnym aktem ze wspólnoty konfesyjnej GIODO zyskiwałby swoje ,zwyczajne" uprawnienia wobec danych osobowych przetwarzanych przez związek wyznaniowy.

Ostatecznie w powołanym na wstępie postanowieniu Naczelny Sąd Administracyjny odmówił podjęcia uchwały uznając, że kwestie te nie wzbudzają już wątpliwości w orzecznictwie sądów administracyjnych. Uzasadniając swoją decyzję - co oczywiste z punktu widzenia jej treści oraz zakresu wniosku RPO - Naczelny Sąd Administracyjny odniósł się jedynie do problemu udowodnienia wystąpienia formalnym aktem z Kościoła, pomijając kwestie żądania wykreślenia wpisów odnoszących się do apostaty w wyznaniowych zbiorach danych. Bez wątpienia powyższe kwestie dotykają przede wszystkim konstytucyjnej pozycji kościołów i innych związków wyznaniowych oraz ściśle z nią związanej (a właściwie będącej jej podstawą) wolności sumienia i religii. Stąd też rozwiązania powyższych wątpliwości należy poszukiwać przede wszystkim analizując przepisy wyznaniowe Konstytucji $\mathrm{RP}^{11}$.

3179/15; wyrok NSA z dnia 9 lutego 2016 roku, sygn. akt I OSK 579/15; wyrok NSA z dnia 9 lutego 2016 roku, sygn. akt I OSK 1466/15; wyrok NSA z dnia 9 lutego 2016 roku, sygn. akt I OSK 2585/15; wyrok NSA z dnia 9 lutego 2016 roku, sygn. akt I OSK 2691/15.

11 Dz. U. z 1997 r. Nr 78, poz. 483 z późn. zm. 


\section{ZAKRES AUTONOMII I NIEZALEŻNOŚCI ZWIĄZKÓW WYZNANIOWYCH}

Pozycję prawną kościołów i innych związków wyznaniowych - a więc wspólnot powołanych w celu wyznawania i szerzenia wiary religijnej, posiadających własny ustrój, doktrynę i obrzędy religijne ${ }^{12}$ - polski ustrojodawca uregulował w art. 25 Konstytucji RP. Oczywiście, dla pełnej rekonstrukcji pozycji normatywnej związków wyznaniowych w obowiązującej konstytucji konieczna byłaby analiza każdego przepisu składającego się na art. 25 ustawy zasadniczej. Jednak na potrzeby niniejszego opracowania nie jest to zabieg konieczny - ze względu na cel i zakres przetwarzania danych osobowych kluczowe znaczenie ma pojęcie autonomii i niezależności tych wspólnot określone w art. 25 ust. 3. Zasadniczy problem sprowadza się do wątpliwości, czy autonomia i niezależność związków wyznaniowych obejmuje (i ewentualnie w jakim zakresie) także przetwarzanie danych osobowych osób, które wystąpiły ze wspólnoty.

Autonomia jest jednym z podstawowych pojęć definiujących pozycję prawną kościołów w Rzeczypospolitej Polskiej. Zgodnie z obowiązującą Konstytucją autonomia przysługuje jedynie dwóm rodzajom osób prawnych: związkom wyznaniowym (art. 25 ust. 3) oraz szkołom wyższym (art. 70 ust. 5). Jak słusznie zauważył Trybunał Konstytucyjny w wyroku z 5 października 2005 roku $^{13}$,,autonomia obu tych instytucji nie jest taka sama, co wynika już z przepisów Konstytucji o niej stanowiących. W szczególności art. 70 ust. 5 Konstytucji zapewnia szkołom wyższym autonomię «na zasadach określonych w ustawie», sygnalizując w ten sposób dopuszczalność ustawowych ograniczeń”. W tym samym judykacie TK stwierdza, że pojęcie autonomii z normatywnego punktu widzenia oznacza po prostu, że dana społeczność może rządzić się własnym prawem. Należy pamiętać, że w przypadku związków wyznaniowych ustrojodawca użył dodatkowo - w koniunkcji z „autonomią” - terminu „niezależność”. Stąd też zbieżność terminologiczna pomiędzy autonomią szkół wyższych oraz

12 Art. 2 pkt 1 ustawy z dnia 17 maja 1989 r. o gwarancjach wolności sumienia i wyznania, tekst jedn. Dz. U. z 2017 r., poz. 1153.

13 Wyrok Trybunału Konstytucyjnego z dnia 5 października 2005 r., sygn. akt SK 39/05, Lex nr 165350. 
związków wyznaniowych nie idzie w parze z tożsamością normatywną tych rozwiązań. „Autonomia i niezależność” to jeden i niepodzielny termin legalny, odnoszący się w obowiązującej ustawie zasadniczej jedynie do wspólnot wyznaniowych i wyrażający ideę organizacyjnej oraz funkcjonalnej odrębności organów i instytucji wspólnoty politycznej i wyznaniowej ${ }^{14}$. Jak stwierdził Trybunał Konstytucyjny w wyroku z dnia 14 grudnia 2009 roku $^{15}$ pojęcia autonomii i niezależności odnoszą się do dwóch aspektów tej samej sytuacji. Autonomia ma związek ze sferą wewnętrzną i oznacza prawo do samodzielnego rozstrzygania o sprawach danego podmiotu, natomiast niezależność dotyczy relacji zewnętrznych i jest rozumiana jako brak podporządkowania innym podmiotom. Stąd też związki wyznaniowe posiadają uprawnienie do tworzenia norm prawnych regulujących wewnętrzne sprawy wspólnoty oraz nie podlegają w tych kwestiach pod jakąkolwiek jurysdykcję organów państwowych. Konsekwencją takiej formy uregulowania statusu wspólnot wyznaniowych jest: z jednej strony nieskuteczność prawa wewnętrznego związków wyznaniowych na forum publicznoprawnym, z drugiej zaś niemożność uregulowania przez prawodawcę państwowego spraw religijnych i organizacyjnych tych wspólnot ${ }^{16}$. W przypadku Kościoła Katolickiego ochrona autonomii i niezależności wynika także z art. 1 Konkordatu ${ }^{17}$, zgodnie z którym Rzeczpospolita Polska i Stolica Apostolska potwierdzają, że Państwo i Kościół Katolicki są - każde w swej dziedzinie - niezależne i autonomiczne oraz zobowiązują się do pełnego poszanowania tej zasady we wzajemnych stosunkach.

Zagwarantowanie wspólnotom wyznaniowym autonomii i niezależności w ramach państwa służy zabezpieczeniu wolności religii zakorzenionej w przyrodzonej godności ludzkiej (por. art. $53 \mathrm{w}$ zw. z art. 30 Konstytucji RP). Stąd też państwo jedynie uznaje i gwarantuje autonomię związków wyznaniowych. Wydaje się, że zagwarantowanie autonomii i niezależności wspólnot wyznaniowych jest jedynym narzędziem, którym państwo bezstronne w sprawach przekonań religijnych i światopoglądowych - a do

14 Olszówka 2016, 157.

15 Wyrok Trybunału Konstytucyjnego z dnia 14 grudnia 2009 r., sygn. akt K 55/07, Lex nr 531412.

16 Szymanek 2005, 28.

17 Konkordat między Stolicą Apostolską i Rzecząpospolitą Polską podpisany w Warszawie dnia 28 lipca 1993 r., (Dz. U. z 1998 r. Nr 51, poz. 318). 
takich należy Rzeczpospolita Polska - może zapewnić pełną swobodę w wyznawaniu i praktykowaniu religii. Przyjęcie przez państwo i jego organy roli organizatorów życia religijnego obywateli (ewentualnie innych osób przebywających na jego terytorium) nieuchronnie prowadzi do praktycznego zastosowania którejś z koncepcji państwa wyznaniowego, w którym można liczyć na prawną ochronę i wsparcie tych wierzeń, które zyskują aprobatę państwa. Co prawda samo przyjęcie przez ustrojodawcę koncepcji państwa wyznaniowego nie musi oznaczać uniemożliwienia, czy utrudnienia praktykowania innej religii niż oficjalna, jednak w takich sytuacjach o faktycznym zakresie dopuszczalnego korzystania $\mathrm{z}$ wolności religijnej decydują najczęściej czynniki pozaprawne, związane np. z przemianami socjologicznymi ${ }^{18}$. Z drugiej strony należy zauważyć, że polski ustrojodawca, gwarantując związkom wyznaniowym autonomię i niezależność, w żaden sposób - nawet przykładowy - nie sprecyzował zakresu tego pojęcia, co w praktyce może rodzić pewne problemy w dokładnym określeniu sfer, w których organy państwa pozostają niekompetentne.

W orzecznictwie polskiego sądu konstytucyjnego - podobnie jak w doktrynie prawa - za sferę przynależącą do autonomii związków wyznaniowych uznaje się ,prawo wspólnot religijnych do samodzielnego decydowania o swoich sprawach wewnętrznych, w szczególności określania treści swojej wiary, struktur organizacyjnych oraz obsadzania stanowisk kościelnych"19. P. Stanisz wyróżnia pięć sfer wchodzących w zakres autonomii i niezależności kościołów: sprawy dogmatyczne, doktrynalne i kultowe; zarząd i organizację związków wyznaniowych; tworzenie materialnych warunków działalności religijnej; propagowanie wyznawanej wiary; działalność wynikająca z przyjmowanej doktryny ${ }^{20}$. Z zasady autonomii i niezależności wynika także - co zostało już zasygnalizowane - nieobowiązywanie prawa wewnętrznego związków wyznaniowych w państwowym porządku prawnym. Jednak nie oznacza to izolacji państwa i kościołów, ani tworzonych przez nie porządków normatywnych. Stąd też normy prawa wewnętrznego związków wyznaniowych powinny być brane pod

18 Borecki 2017, 245.

19 Wyrok Trybunału Konstytucyjnego z dnia 14 grudnia 2009 r, sygn. akt K 55/07, Lex nr 531412.

20 Stanisz 2008, 76-77. 
uwagę przy wydawaniu przez organy władzy publicznej rozstrzygnięć dotyczących wspólnot religijnych ${ }^{21}$. Jednocześnie władze państwowe są pozbawione jakichkolwiek kompetencji w sferze wchodzącej w zakres autonomii związków wyznaniowych - a więc np. w ustalaniu doktryny wiary, czy też zasad członkostwa. Natomiast ingerując w sferę działalności związków wyznaniowych - zarówno poprzez tworzenie, jak i stosowanie prawa - państwo powinno zachowywać powściągliwość ${ }^{22}$.

Podsumowując tę część rozważań można stwierdzić, że zasada autonomii i niezależności określa pełną samodzielność związków wyznaniowych wobec władzy państwowej w sprawach należących do ich zakresu działania. A więc treść tej zasady koncentruje się przede wszystkim na „własnym zakresie” działalności podmiotów wyznaniowych. Mówiąc inaczej poza ingerencją państwa pozostają wszystkie sytuacje, w których wspólnota wyznaniowa występuje jako podmiot realizujący wolności religijne swoich członków. W tym zakresie mieści się nie tylko zdefiniowanie doktryny religijnej, ale również określenie organizacji terytorialnej związku wyznaniowego, czy zarządzania i administrowania jego sprawami ${ }^{23}$ w tym np. w kwestii ustalenia zasad przystępowania do posług religijnych sprawowanych przez związek wyznaniowy. Skoro zaś ustrojowa pozycja związków wyznaniowych wynika z deklarowanej w Konstytucji RP wolności sumienia i religii, wszelkie ograniczenia ich autonomii i niezależności muszą być zgodne z kryteriami określonymi w art. 53 ust. 5 ustawy zasadniczej. A więc jakiekolwiek ograniczenia autonomii i niezależności związków wyznaniowych winny być konieczne do ochrony bezpieczeństwa państwa, porządku publicznego, zdrowia, moralności oraz wolności i praw innych osób. Ponadto muszą być to ograniczenia konieczne w społeczeństwie demokratycznym, a także nie mogą one naruszać istoty wolności do uzewnętrzniania religii. Można zaryzykować twierdzenie, że skoro autonomia i niezależność związków wyznaniowych bezpośrednio służy zabezpieczeniu wolności religijnej - jednego z podstawowych praw człowieka - wątpliwości co do zakresu tej zasady należy zawsze rozstrzygać na korzyść autonomii. W świetle tej tezy konieczna jest ocena, czy można

\footnotetext{
21 Dudek 2004, 207; Stanisz 2015, 166 i 169.

22 Olszówka 2016, 155-156.

23 Garlicki 2016.
} 
ograniczyć autonomię i niezależność wspólnot konfesyjnych w związku $\mathrm{z}$ realizacją praw byłych wyznawców w zakresie przetwarzania ich danych osobowych.

\section{KONSEKWENCJE ROZWIĄZAŃ KONSTYTUCYJNYCH DLA} PRZETWARZANIA DANYCH OSOBOWYCH PRZEZ ZWIĄZKI WYZNANIOWE

Zgodnie z art. 27 ust. 2 pkt 4 UODO związki wyznaniowe miały prawo przetwarzać dane osobowe ujawniające pochodzenie rasowe lub etniczne, poglądy polityczne, przekonania religijne lub filozoficzne, przynależność wyznaniową, partyjną lub związkową, jak również dane o stanie zdrowia, kodzie genetycznym, nałogach lub życiu seksualnym oraz dane dotyczące skazań, orzeczeń o ukaraniu i mandatów karnych, a także innych orzeczeń wydanych w postępowaniu sądowym lub administracyjnym. Za warunek przetwarzania tych danych przez kościoły i inne związki wyznaniowe uznano „niezbędność” tej czynności dla wykonywania statutowych zadań wspólnot. Ponadto przetwarzanie mogło dotyczyć wyłącznie członków związków wyznaniowych albo osób utrzymujących z nimi stałe kontakty w związku z ich działalnością. Koniecznym było także zapewnienie pełnych gwarancji ochrony przetwarzanych danych. Ponadto związki wyznaniowe o uregulowanej sytuacji prawnej zostały zwolnione $\mathrm{z}$ obowiązku rejestracji zbioru danych dotyczących wyznawców i przetwarzanych na potrzeby wspólnoty (art. 43 ust. 1 pkt 3 UODO).

W stosunku do tego typu zbioru danych wyłączono szereg uprawnień Generalnego Inspektora Ochrony Danych Osobowych, np. w zakresie wydawania decyzji administracyjnych - w tym nakazujących przywrócenie stanu zgodnego z prawem - i rozpatrywanie skarg w sprawach wykonania przepisów o ochronie danych osobowych, czy przeprowadzania oględzin urządzeń, nośników oraz systemów informatycznych służących do przetwarzania danych (art. 43 ust. 2 UODO). Uprawnienia GIODO w stosunku do danych przetwarzanych przez związki wyznaniowe zostały ograniczone, ale nie całkowicie wyłączone ${ }^{24}$. Dlatego w doktrynie wskazuje się, że Generalny Inspektor Ochrony Danych Osobowych zachowuje kompeten-

24 Mezglewski 2007,11. 
cje określone w art. 14 pkt 2 ustawy o ochronie danych ${ }^{25}$. A więc może on żądać złożenia pisemnych lub ustnych wyjaśnień oraz wzywać i przesłuchiwać osoby w zakresie niezbędnym do ustalenia stanu faktycznego.

Specyfika związków wyznaniowych dotyczy nie tylko ich celu, czy struktury, ale również sposobów nabycia bądź utraty członkostwa - mającego kluczowe znaczenie w perspektywie przetwarzania danych osobowych przez tego rodzaju wspólnoty ${ }^{26}$. Jak już wielokrotnie podkreśliliśmy zagadnienia określenia zasad członkostwa w związku wyznaniowym wchodzą w zakres jego autonomii i niezależności - a więc organy państwa (a takim bez wątpienia jest GIODO) nie mają prawa zarówno normować tych kwestii, jak i oceniać skuteczności przyjęcia lub wykluczenia osoby ze wspólnoty wyznaniowej. Konstatacja ta wynika także z brzmienia art. 32 ust. 2 pkt 8 ustawy o gwarancjach wolności sumienia i wyznania, w którym ustawodawca postanowił, że kwestia nabycia i utraty członkostwa powinna zostać rozstrzygnięta w statucie związku wyznaniowego. Jednak otwartym pozostaje pytanie, czy „nabycie i utrata członkostwa” wiąże się ze składaniem oświadczeń woli, czy też z podejmowaniem czynności niemieszczących się w tego typu kwalifikacjach. Jest to kluczowa wątpliwość w perspektywie argumentacji pojawiającej się w drugiej grupie orzeczeń, czy decyzji GIODO zakładających możliwość kontroli przez organy państwowe skuteczności wystąpienia ze związku wyznaniowego na podstawie przepisów powszechnie obowiązującego prawa dotyczącego składania oświadczeń woli ${ }^{27}$, a w konsekwencji żądania przez byłego wyznawcę zaprzestania przetwarzania jego danych osobowych.

Warto wziąć pod uwagę, że „sposób nabycia i utraty członkostwa” musi zostać określony także w statucie stowarzyszenia ${ }^{28}$ - organizacji najbardziej zbliżonej do związku wyznaniowego. Na kanwie tych rozwiązań podnosi się w orzecznictwie, że nabycia członkostwa w stowarzyszeniu następuje na podstawie zgodnych oświadczeń woli stowarzyszenia i przystępującego, natomiast wystąpienie z tej organizacji dochodzi do skutku

25 Sobczyk 2010, 156.

26 Mezglewski 2017, 376.

27 Wyrok Naczelnego Sądu Administracyjnego z dnia 18 października 2013 r., sygn. akt I OSK 1339/13, Centralna Baza Orzeczeń Sądów Administracyjnych.

28 Art. 10 ust. 1 pkt 4 ustawy z dnia 7 kwietnia 1989 r. - Prawo o stowarzyszeniach, tekst jedn. Dz. U. z 2017 r., poz. 210. 
w wyniku jednostronnego oświadczenia woli. Poza tym, orzecznictwo sam statut stowarzyszenia uznaje za umowę cywilnoprawną, zawartą przez założycieli, do której przystępują kolejni członkowie ${ }^{29}$. Jeżeli teorię tę przenieść na grunt związków wyznaniowych należałoby uznać, że do skutecznego wystąpienia ze związku wyznaniowego wystarczy samo oświadczenie woli jego członka, które można ocenić na podstawie zasad prawa cywilnego - a tym samym akty prawa wewnętrznego wspólnot konfesyjnych mają charakter umów cywilnoprawnych. Jednak wydaje się, że w kwestii ustalania przynależności do związku wyznaniowego koncepcja oświadczenia woli jest w ogóle nieprzydatna.

Przede wszystkim należy mieć na względzie, że ze względu na religijny charakter związków wyznaniowych uzyskiwanie w nich członkostwa najczęściej połączone jest nie ze składaniem jakichkolwiek oświadczeń (woli), ale ze spełnianiem określonych praktyk rytualnych. Religijny charakter tych czynności wyklucza ich cywilnoprawną ocenę, a więc pomimo tego, że ustawodawca zarówno w stosunku do statutu związku wyznaniowego, jak i np. stowarzyszenia użył tych samych określeń, ich normatywna treść nie jest tożsama. W polskich warunkach modelowym przykładem takiej sytuacji jest Kościół Katolicki, a także inne wspólnoty chrześcijańskie, w których członkostwo nabywa się na mocy przyjęcia sakramentu chrztu. W teologii chrześcijańskiej określa się, że wywiera on „niezatarty charakter" - a więc mówiąc inaczej ten, kto raz stał się chrześcijaninem nie może przestać nim być. Z tego punktu widzenia apostazja stanowi jedynie zerwanie pełnej wspólnoty z Kościołem ${ }^{30}$. Oczywiście, co również zostało już podkreślone, regulacje prawa wewnętrznego związków wyznaniowych nie są skuteczne na forum państwowym, co jednak nie oznacza, że organy państwa mogą prowadzić samodzielne ustalenia w zakresie regulowanym przez prawodawcę kościelnego. Skoro zaś przystępowanie i występowanie ze związku wyznaniowego jest bezpośrednio związane z praktykowaniem religii - a więc sferą autonomii i niezależności wspólnot konfesyjnych -

29 Wyrok Sądu Najwyższego z dnia 24 czerwca 2009 r., sygn. akt I CSK 535/08, Lex nr 518133; wyrok Sądu Apelacyjnego w Katowicach z dnia 27 maja 2015 r., sygn. akt I ACa 176/15, Lex nr 1754174; wyrok Sądu Apelacyjnego w Szczecinie z dnia 30 kwietnia 2015 r., sygn. akt I ACa 214/15, Lex nr 1782041.

30 Czelny 2018, 203. 
organy państwa nie mają uprawnień i narzędzi do oceny skuteczności dokonania tych aktów.

Oczywistym jest, że wraz z dokonaniem takiego aktu związek wyznaniowy przestaje zbierać dane dotyczące członka. Wynika to chociażby z faktu, że były wyznawca przestaje utrzymywać jakiekolwiek relacje ze wspólnotą wyznaniową, stąd też brak ,źródła” z którego można by pozyskiwać dane. Przykładowo zgodnie z obowiązującym Dekretem Ogólnym Konferencji Episkopatu Polski w sprawie wystąpienia z Kościoła oraz powrotu do wspólnoty Kościoła ${ }^{31}$ po zakończeniu procedury apostazji dokonuje się stosownej adnotacji o tym fakcie w księdze ochrzczonych (pkt 7-8), co praktycznie kończy formalne relacje pomiędzy Kościołem Katolickim a ochrzczonym w nim apostatą. Co nie oznacza, że informacja o członkostwie przestaje mieć znaczenie dla religijnej działalności związku wyznaniowego ${ }^{32}$.

Zgromadzone przez związek wyznaniowy dane osobowe osoby, która wystąpiła ze wspólnoty, mają charakter historyczny - jedynie potwierdzają fakt bycia członkiem związku wyznaniowego oraz zaprzestania praktykowania religii w danym kościele. Stąd też za celne należy uznać - wydane prawdopodobnie pod wpływem orzecznictwa NSA z września 2016 roku stanowisko GIODO wyrażone w decyzjach z dnia 16 grudnia 2016 roku $^{33}$. Generalny Inspektor Ochrony Danych Osobowych stwierdził w nich, że dane osobowe byłego członka związku - jako historyczne - podlegają pod reżim ustawy z dnia 14 lipca 1983 roku o narodowym zasobie archiwalnym i archiwach ${ }^{34}$. Na mocy art. 1 tej ustawy do Narodowego Zasobu Archiwalnego, zostały zaliczone m.in. materiały zawierające informacje o wartości historycznej, o działalności organizacji o charakterze wyznaniowym, powstające zarówno w przeszłości, jak i współcześnie. Kościoły i inne związki wyznaniowe, u których powstają bądź które przechowują materiały archiwalne, są obowiązane zapewnić należyte warunki ich przechowywania, chronić je przed uszkodzeniem, zniszczeniem bądź utratą oraz zapewnić konieczną konserwację tych materiałów (art. 12 ustawy

31 Akta Konferencji Episkopatu Polski Nr 27/2015, 101-104.

32 Walencik 2013, 21.

33 Znak: DOLiS/DEC-1348/16/108126, niepublik., mps w zbiorach autora. W zakresie zmian w praktyce GIODO dotyczącej przetwarzania danych osobowych byłych wyznawców zob. Bielecki 2017, 280.

34 Tekst jedn. Dz. U. z 2018 r., poz. 217, dalej: ustawa o archiwach. 
o archiwach). Oczywistym jest, że jednym z najważniejszych elementów ochrony materiałów archiwalnych jest zapewnienie ich integralności poprzez uniemożliwienie nanoszenia na nie jakichkolwiek zmian. Jednocześnie dokładne uregulowanie powyższych spraw ustawodawca powierzył związkom wyznaniowym (art. 13 ustawy o archiwach), które są w tym zakresie ograniczone jedynie koniecznością ewidencjonowania, przechowywania i zabezpieczenia materiałów archiwalnych, wyłączeniem ich z obrotu oraz przekazaniem ich na własność państwa w przypadku zaprzestania działalności przez związek wyznaniowy (art. 43-45 ustawy o archiwach) ${ }^{35}$. Stąd też bez względu na zakres wewnątrzkonfesyjnych unormowań w tym zakresie związki wyznaniowe są zobowiązane do ochrony swoich archiwaliów na mocy prawa państwowego ${ }^{36}$ - a tym samym należy uznać, że prawodawca państwowy wyłączył przepisem prawa powszechnie obowiązującego możliwość dokonywania zmian w materiałach archiwalnych wytworzonych w ramach działalności związku wyznaniowego.

W tym kontekście warto wskazać, że zgodnie z art. 5 Konstytucji, Rzeczpospolita Polska strzeże - obok niepodległości i nienaruszalności swojego terytorium - dziedzictwa narodowego. Jak wskazuje się w doktrynie jest to przepis określający najbardziej podstawowe cele państwa ${ }^{37}$, zaś sam termin „dziedzictwo narodowe” należy rozumieć szeroko, obejmując jego zakresem całość materialnego i niematerialnego dorobku narodu - nawet jeżeli nie znajduje się on pod szczegółową ochroną przepisów ustawowych $^{38}$. W świetle preambuły do obowiązującej Konstytucji polska kultura zakorzeniona jest w „chrześcijańskim dziedzictwie narodu i ogólnoludzkich wartościach", stąd można wnioskować, że ustrojodawca szczególnie wyakcentował tę sferę dziedzictwa narodowego, która wynika z aktywności chrześcijańskich związków wyznaniowych. A więc bez wątpienia są one zobowiązane do zachowania swojej spuścizny, jako kluczowego komponentu „dziedzictwa narodowego”. Co prawda przetwarzanie danych osobowych obejmuje także ich przechowywanie (art. 7 pkt 2 UODO), jednak legalność ich przetwarzania oznacza postępowanie, które jest zgodne

35 Konstankiewicz, Niewęgłowski 2016, 163-164.

36 Zeidler 2007, 111.

37 Sarnecki 2016, 139.

38 Zeidler 2004, 3445,353. 
nie tylko z przepisami ustawy o ochronie danych, ale również z przepisami innych ustaw i aktów wykonawczych ${ }^{39}$. Należy pamiętać, że zgodnie z nieobowiązującą już ustawą o ochronie danych osobowych, przetwarzanie danych osobowych było dopuszczalne nie tylko na podstawie zgody osoby, której dotyczyły, ale również w przypadku, gdy było to niezbędne dla wypełnienia prawnie usprawiedliwionych celów realizowanych przez administratorów danych (art. 23 ust. 1 pkt 5 UODO). Za taki - w świetle powyżej poczynionych ustaleń - bez wątpienia można uznać zabezpieczenie integralności archiwaliów wytworzonych przez związek wyznaniowy.

Jak słusznie wskazał Naczelny Sąd Administracyjny w wyroku z dnia 9 lutego 2016 r., sygn. akt I OSK 2691/15 całkowite porzucenie wiary lub wystąpienie z Kościoła - niezależnie od oceny dopuszczalności tej ostatniej czynności w świetle prawa kościelnego - nie stanowi żadnego uzasadnienia dla zatarcia pewnych, w przeszłości zaszłych faktów. Uzasadniając swoje stanowisko NSA podkreślił, że prawo powszechnie obowiązujące nie przewiduje obowiązku zatarcia informacji o uczestnictwie obywatela w działalności jakiejkolwiek organizacji. Idąc tym tokiem rozumowania można - w ślad za Naczelnym Sądem Administracyjnym - wskazać wiele przykładów takich sytuacji. Obywatelowi, który zmieni poglądy polityczne i wystąpi z partii, której był członkiem, nie służy prawo skutecznego domagania się usunięcia z rejestru członków tej partii wpisów, potwierdzających fakt członkostwa. Analogiczne zasady dotyczą byłych członków korporacji zawodowych, czy osób zmieniających stan cywilny. Przyjęcie odmiennej wykładni prowadziłoby do sytuacji właściwie zupełnego zniweczenia możliwości korzystania $\mathrm{z}$ wielu praw podmiotowych (w tym w zakresie wolności religii), jak i prowadzenia badań naukowych - przede wszystkim w dziedzinie nauk historycznych i społecznych. To z kolei prowadziłoby do znacznego uszczuplenia polskiego dziedzictwa narodowego.

Jednak przede wszystkim posiadanie przez związek wyznaniowy informacji o historii członkostwa w nim poszczególnych wyznawców jest niezbędne dla zapewnienia realizacji praw osób trzecich ${ }^{40}$, które postanowiły praktykować religię w danej wspólnocie wyznaniowej. Znowu za modelo-

39 Wyrok Naczelnego Sądu Administracyjnego z dnia 18 kwietnia 2018 r., sygn. akt I OSK 1354/16, Centralna Baza Orzeczeń Sądów Administracyjnych.

40 Mezglewski 2008, 211. 
wy przykład takiej sytuacji mogą posłużyć rozwiązania prawne Kościoła Katolickiego. W aktualnie obowiązującym prawodawstwie kanonicznym nawet wystąpienie z Kościoła formalnym aktem nie zwalnia ochrzczonego z podlegania pod przepisy Kodeksu Prawa Kanonicznego dotyczące zawarcia sakramentalnego małżeństwa, m.in. w zakresie przeszkody różności religii, formy kanonicznej oraz zawarcia małżeństwa mieszanego ${ }^{41}$. Mówiąc inaczej katolik, który formalnym aktem odłączył się od Kościoła Katolickiego, jest nadal zobowiązany do zachowania formy kanonicznej podczas zawierania małżeństwa ${ }^{42}$. Stąd też usunięcie z kościelnego zbioru wszelkich danych dotyczących byłego członka oznaczałoby uniemożliwienie wykonywania statutowych celów wspólnoty. Wydaje się, że kwestia ta dotyczy nie tylko ewentualnego zawarcia małżeństwa w Kościele Katolickim. Każdy związek wyznaniowy może stanąć przed problemem chęci powrotu do wspólnoty byłego wyznawcy, czy wejścia obecnego członka w jakąś religijną interakcję z nim - co z kolei uzasadnia potrzebę posiadania informacji o „religijnej historii” tej osoby. Nie jest rzeczą państwa ocena zasadności wierzeń, sposobów ich wyrażania ${ }^{43}$, czy przyjętych na ich podstawie regulacji, a więc tym samym konieczności przetwarzania danych dotyczących historii członkostwa. W przeciwnym razie zarówno ochrona wolności sumienia i wyznania, jak i służąca jej autonomia i niezależność związków wyznaniowych stały by się prawami w dużej mierze iluzorycznymi. Związek wyznaniowy mógłby przyjąć określoną doktrynę, np. zabraniającą powtórnego małżeństwa pomiędzy ochrzczonymi, a jednocześnie zostałby pozbawiony możliwości jej egzekwowania. Skoro tego typu dane nie mogą być przetwarzane przez władze państwowe, a wyznawca może żądać ich wykreślenia z rejestrów wyznaniowych, to zakres wolności religijnej innych osób oraz autonomii i niezależności kościołów zostaje uzależniony od woli apostaty. Nie sposób przyjąć, że wola jednostki może przekreślić konstytucyjny status jakiejkolwiek organizacji.

Dokonując wykładni przepisów prawa niedopuszczalnym jest wyciąganie wniosków, które zupełnie przekreślają cel regulacji. W świetle

41 Góralski 2015, 4.

42 Wentz 2010, 149.

43 Wyrok Trybunału Konstytucyjnego z dnia 10 kwietnia 2014 r., sygn. akt K 52/13, Lex nr 1633060. 
całokształtu niniejszych rozważań jasnym jest, że przetwarzanie danych osobowych - zarówno byłych, jak i obecnych członków - przez związki wyznaniowe jest objęte sferą autonomii i niezależności wspólnot wyznaniowych. Stąd też konieczność prokonstytucyjnej wykładni przepisów prawa, jak i jednoznaczny cel regulacji „wyznaniowych” ustawy o ochronie danych osobowych usprawiedliwiają wniosek, że organy państwa (w tym GIODO) są pozbawione jurysdykcji nad zbiorami danych tworzonych przez związki wyznaniowe na potrzeby swojej działalności statutowej. Jak podkreślono w doktrynie ratio legis art. 43 UODO było wyłączenie możliwości ingerencji przez Generalnego Inspektora Ochrony Danych Osobowych w treść ksiąg prowadzonych przez związek wyznaniowy o uregulowanej sytuacji prawnej oraz pozbawienie tego organu administracji możliwości określania, kto jest, a kto nie jest członkiem wspólnoty konfesyjnej ${ }^{44}$. Przyjmowanie innego rozumienia tego przepisu niweczy cel regulacji.

\section{PODSUMOWANIE}

Bez wątpienia polski ustrojodawca potwierdził wyjątkowy status związków wyznaniowych, zwłaszcza w zakresie ich autonomii i niezależności. Ujmując rzecz najogólniej, treść tej zasady obejmuje wszystkie aspekty realizacji wolności sumienia i religii - jednego z fundamentalnych praw człowieka. Zawsze, kiedy związek wyznaniowy występuje jako organizator życia religijnego swoich członków jest wobec państwa autonomiczny i niezależny. Możliwości ograniczenia jego konstytucyjnej pozycji są jednocześnie tożsame z granicami samej wolności uzewnętrzniania religii. Dlatego też państwo nie ma jakichkolwiek kompetencji władczych, zarówno w sferze stanowienia, jak i stosowania prawa w kwestiach związanych z praktykowaniem religii. Pomimo, że z punktu widzenia współczesnego konstytucjonalizmu i doktryny prawa wyznaniowego są to konstatacje oczywiste, ciągle toczy się spór o granice i dokładny zakres autonomii i niezależności kościołów, w tym o możliwości przetwarzania przez związki wyznaniowe danych osobowych swoich byłych członków.

44 Zob. Barta, Fajgielski, Markiewicz 2015. 
Przede wszystkim należy podkreślić, że przetwarzanie danych osobowych - byłych i obecnych członków - przez związki wyznaniowe jest konieczne dla realizacji celu istnienia tych wspólnot, a więc szerzenia i wyznawania wiary religijnej. Przyjęcie odmiennej wykładni prowadziłoby do uniemożliwienia realizacji doktryny przyjętej przez wspólnoty wyznaniowe, a tym samym zabezpieczenia realizacji wolności religijnej swoich członków. Z tych względów bez wątpienia są to kwestie objęte zakresem autonomii i niezależności związków wyznaniowych, które nie mogą zostać ograniczone z powołaniem się np. na prawo do prywatności. Dokonana ostatnio zmiana $\mathrm{w}$ zasadach ochrony danych osobowych potwierdza tę tezę - prawodawca unijny wprost dopuścił możliwość przetwarzania przez związki wyznaniowe danych swoich byłych wyznawców, tym samym niejako wyżej stawiając ochronę wolności religijnej, niż prawo do „bycia zapomnianym”.

Dodatkowo warto wskazać, że zgodnie z polskim prawem dane byłych członków mają charakter historyczny, a tym samym związki wyznaniowe mają obowiązek zapewnienia ich integralności i przechowywania w sposób uniemożliwiający zniszczenie. Dokonywanie zmian np. w księgach metrykalnych parafii mogłoby rodzić odpowiedzialność administratora danych osobowych w związku z niszczeniem Narodowego Zasobu Archiwalnego. Stąd też przepisy dotyczące opieki nad archiwaliami mają charakter specjalny wobec dotyczących ochrony danych osobowych. Ponadto polskie prawodawstwo nie przewiduje możliwości skutecznego żądania zatarcia informacji o fakcie członkostwa w różnego rodzaju organizacjach (np. partiach politycznych, korporacjach zawodowych, czy stowarzyszeniach), których konstytucyjna pozycja nie cieszy się autonomią i niezależnością. A więc tym bardziej nie można domagać się przyznania tego typu uprawnienia w stosunku do faktu bycia członkiem autonomicznego i niezależnego związku wyznaniowego. Stąd też związki wyznaniowe mają prawo, a jednocześnie obowiązek przetwarzania danych osobowych swoich byłych wyznawców.

\section{BIBLIOGRAFIA}

Barta, Janusz, Paweł Fajgielski, Ryszard Markiewicz. 2015. Komentarz do art. 43 ustawy o ochronie danych osobowych, Lex/el. 
Bielecki, Marek. 2017. „Przetwarzanie danych osobowych przez Świadków Jehowy”. Przeglad Prawno-Ekonomiczny 40: 280.

Borecki, Paweł. 2017. „Znamiona państwa wyznaniowego: uwagi na kanwie dorobku współczesnego konstytucjonalizmu". Studia z Prawa Wyznaniowego 20: $223-248$.

Czelny, Michał. 2018. „Procedura wystąpienia z Kościoła katolickiego w kontekście obowiązku aktualizacji danych osobowych". Przegląd Praw Wyznaniowego 10: 197-2018.

Dudek, Dariusz. 2004. „Równouprawnienie kościołów i związków wyznaniowych na tle konstytucyjnych zasad prawa wyznaniowego". W: Prawo wyznaniowe w systemie prawa polskiego, red. Artur Mezglewski, 199-206. Lublin: Towarzystwo Naukowe Katolickiego Uniwersytetu Lubelskiego.

Garlicki, Lech. 2016. Komentarz do art. 25 Konstytucji Rzeczypospolitej Polskiej, Lex/el.

Góralski, Wojciech. 2015. „Problem wystąpienia z Kościoła Katolickiego w Republice Federalnej Niemiec". Prawo Kanoniczne 1: 3-21.

Hucał, Michał. 2017. „Ochrona danych osobowych w związkach wyznaniowych w świetle unijnego rozporządzenia nr 2016/679". Studia z Prawa Wyznaniowego 20: 185-222.

Hucał, Michał. 2018. „Orzecznictwo sądów administracyjnych w sprawach dotyczących przetwarzania danych osobowych przez związki wyznaniowe”. Przeglad Prawa Wyznaniowego 10: 5-23.

Konstankiewicz, Marek, Adrian Niewęgłowski. 2016. Narodowy zasób archiwalny $i$ archiwa. Komentarz. Warszawa: Wolters Kluwer.

Mezglewski, Artur. 2007. „Działalność związków wyznaniowych a ochrona danych osobowych". Studia z Prawa Wyznaniowego 10: 5-21.

Mezglewski, Artur. 2008. „Administrowanie danymi osobowymi”. W: Artur Mezglewski, Henryk Misztal, Piotr Stanisz, Prawo wyznaniowe, 207-211. Warszawa: C.H. Beck.

Mezglewski, Artur. 2017. „Opinia prawna w sprawie uprawnień informacyjnych oraz rektyfikacyjnych członków związków wyznaniowych w odniesieniu do danych osobowych przetwarzanych przez związki wyznaniowe w ramach ich działalności statutowej”. Studia z Prawa Wyznaniowego 20: 373-382.

Olszówka, Marcin. 2016.Wpływ Konstytucji RP z 1997 roku na system źródet prawa wyznaniowego. Warszawa: Oficyna Wydawnicza Uczelni Łazarskiego.

Sarnecki, Paweł. 2016. „Komentarz do art. 5 Konstytucji Rzeczypospolitej Polskiej". W: Konstytucja Rzeczypospolitej Polskiej. Komentarz. Tom I, wyd. II, red. Lech Garlicki, Marek Zubik, 135-140. Warszawa: Wydawnictwo Sejmowe. 
Sobczyk, Paweł. 2010. „Ograniczenia praw podmiotów ze względu na przetwarzanie danych osobowych dotyczących przekonań religijnych i przynależności wyznaniowej. Studia z Prawa Wyznaniowego 13: 143-159.

Stanisz, Piotr. 2008. „Naczelne zasady instytucjonalnych relacji państwo-kościół”. W: Artur Mezglewski, Henryk Misztal, Piotr Stanisz, Prawo wyznaniowe, 7677. Warszawa: C.H. Beck.

Stanisz, Piotr. 2015. „Konstytucyjne zasady określające relacje państwa z kościołami i innymi związkami wyznaniowymi: autonomia i niezależność oraz współdziałanie". W: Katolickie zasady relacji państwo-Kościół a prawo polskie, red. Józef Krukowski, Mirosław Sitarz, Henryk Stawniak, 158-170. Lublin: Towarzystwo Naukowe Katolickiego Uniwersytetu Lubelskiego.

Szymanek, Jarosław. 2005 „Klauzule wyznaniowe w Konstytucji RP”. Studia z Prawa Wyznaniowego 8: 5-43.

Walencik, Dariusz. 2013. „Przetwarzanie danych osobowych przez związki wyznaniowe a uprawnienia Generalnego Inspektora Ochrony Danych Osobowych". Forum Prawnicze 2: 8-22.

Wentz, Wiesław. 2010. „Apostazja i formalny akt wystąpienia z Kościoła: zasady postępowania w świetle norm kanonicznych". Studia Salvatoriana Polonica 4: $129-151$.

Zeidler, Kamil. 2004. „Pojęcie «dziedzictwa narodowego» w Konstytucji RP i jego prawna ochrona". Gdańskie Studia Prawnicze 12: 343-353.

Zeidler, Kamil. 2007. Prawo ochrony dziedzictwa kultury. Warszawa: Wolters Kluwer.

\section{THE RIGHT AND THE OBLIGATION TO PROCESS PERSONAL DATA OF EX-BELIEVERS OF CHURCHES AND OTHER RELIGIOUS ORGANIZATIONS}

Sum mary

The Constitution of the Republic of Poland guarantees autonomy and independence for churches and other religious organizations. This principle aim to guarantee the effective implementation of an individual's right to religious freedom. In order to achieve their goals, religious organizations have to process personal data of their members. However, the problem that appears in practice is whether the processing of personal data of an ex-believer should cease after he or she makes a formal act of defection from a church. So far, the relevant legal literature and case-law have proposed a few solutions to the above-mentioned problem. 
The article attempts to determine whether the constitutional status of religious organizations makes them entitled to process personal data of ex-believers, using the decision of the Supreme Administrative Court of 21 May 2018 as the basis for analysis. The answer to this question is affirmative, as the Author maintains that processing of personal data of ex-believers by religious organizations is both essential for the realization of religious freedom of other worshippers and it is required due to the provisions of universally binding law. According to the Act on the National Archival Resource and Archives, the personal data of ex-members of religious organizations are part of the National Archival Resource, and thus every church is obliged to protect them and cannot make any modification of their content. Therefore, apostates do not have the right to demand removal of their personal data from the records maintained by churches and other religious organizations. Compliance with such a demand could make a personal data administrator liable for the violation of data protection laws.

Key words: processing of personal data; autonomy and independence; religious organization; apostasy 